\title{
Peningkatan Hasil Belajar Matematika Dengan Menggunakan Model Pembelajaran Matematika Realistik Kelas III SDN Payungan 01
}

\author{
Anik Wahyuningsih \\ Program Studi PGSD-FKIP Universitas Kristen Satya Wacana \\ Email:wahyuanik2@gmail.com
}

\begin{abstract}
Abstrak
Tujuan penelitian yang akan dicapai adalah untuk meningkatkan hasil belajar matematika materi pecahan melalui model pembelajaran Matematika Realistik kelas 111 SDN Payungan 01 kwcamatan kaliwungu Semarang tahun pelajaran 2013/2014. Subjek penelitian tindakan kelas yaitu peserta didik kelas 111 SDN Payungan 01 yang berjumlah 20 peserta didik. Bentuk penelitian ini adalah penelitian tindakan kelas dengan menggunakan dua siklus. Berdasarkan hasil penelitian melalui model pembelajaran Matematika Realistik dapat meningkatkan asil belajar matematika materi pecahan pada peserta didik kelas 111 SD Negeri Payungan 01. Hal ini dapat dilihat dari kegiatan pembelajaran matematika dengan meningkatnya hasil belajar matematika pada peserta didik. Peningkatan ini dapat dilihat dari hasil tes matematika peserta didik yang menunjukkan adanya peningkatan, yaitu pada siklus 1 menunjukkan nilai rata - rata kelas mencapai 71,25 dan ketuntasan klasikalnya $65 \%$. Pada siklus 11 nilai rata-rata kelas naik menjadi 78,25 dan ketuntasan klasikal juga meningkat menjadi $95 \%$. Dengan demikian dapat disimpulkan bahwa pembelajaran matematika materi pecahan melalui model pembelajaran Matematika Realistik dapat meningkatkan hasil belajar matematika materi pecahan pada peserta didik kelas 111 SDN Payungan 01 taun pelajaran 2016/2017.
\end{abstract}

Kata kunci: Hasil Belajar; Matematika; Matematika Realistik

\section{Improved Mathematics Learning Outcomes Using Realistic Mathematics Learning Model Class III SDN Payungan 01}

\section{Abstract}

The research objective to be achieved is to improve learning outcomes through the shards of material mathematics learning model Realistic Mathematics III grade SDN 01 kwcamatan Kaliwungu Payungan Semarang academic year 2013/2014. Subject of classroom action research that learners class 111 SDN Payungan 01 totaling 20 learners. The shape of this research is classroom action research using two cycles. Based on the research results through Realistic Mathematics learning model can improve mathematics learning acyl material fractions on the learner class III Elementary School Payungan 01. It can be seen from mathematics learning activities with increased mathematics learning outcomes in learners. This increase can be seen from the test results of the math students who showed an increase, ie in cycle 1 shows the value - average grade reaches 71.25 and completeness klasikalnya $65 \%$. In cycle II class average value rose to 78.25 and classical completeness is also increased to $95 \%$. It can be concluded that the study of mathematics material fractions through Realistic Mathematics learning model can improve learning outcomes matter fractions in math class 111 learners SDN Payungan epidemic 01 lessons 2016/2017

Keywords: Learning Outcomes; Mathematics; Mathematics Realistic 


\section{PENDAHULUAN}

Pendidikan Nasional berfungsi untuk mengembangkan kemampuan dan watak serta peradaban bangsa yang bermartabat dalam rangka mencerdaskan kehidupan bangsa, bertujuan untuk mengembangkan potensi siswa agar menjadi manusia yang beriman dan bertaqwa kepada Tuhan Yang Maha Esa, berakhlak mulia, sehat, berilmu, cakap, kreatif, mandiri, dan menjadi warga negara yang demokratis serta bertanggung jawab.

Berdasarkan pada latar belakang masalah diatas dan hasil diskusi dengan teman sejawat dan dosen pengampu mata kuliah maka peneliti dapat mengidentifikasi masalah sebagai berikut : Hasil tes formatif masih dibawah KKM,Pembelajaran terjadi secara monoton,Sebagian siswa belum menguasai materi tentang pecahan,Siswa terlihat pasif karena hanya duduk diam dan terlihat acuh teradap pembelajaran, Guru belum menggunakan model pembelajaran yang inovatif.

Setelah mengetahui kenyataan proses pembelajaran yang penulis laksanakan seperti diatas, maka penulis merefleksi diri dan mendiskusikan dengan teman sejawat dan dosen pengampu mata kuliah. Dari kegiatan ini diketahui faktor penyebab rendahnya penguasaan siswa tetrhadap materi pelajaran yang disampaikan guru adalah sebagai berikut : Kurang tepatnya model dan alat peraga yang digunakan guru,Sikap siswa dalam mendengarkan kurang baik,Guru terlalu cepat dalam menjelaskan materi,Kurangnya pemanfaatan benda-benda kongkrit yang dapat digunakan sebagai pengantar pembelajaran,Guru tidak memberi kesempatan siswa untuk bertanyattentang materi yang belum jelas,Situasi kelas tenang seakan-akan sudah paham tetapi setelah diadakan tes asilnya kurang memuaskan.

Berdasarkan latar belakang yang telah dikemukakan di atas, maka dapat dirumuskan permasalahan sebagai berikut :

Apakah melalui model pembelajaran matematika realistik dapat meningkatkan hasil belajar matematika materi pecahan pada siswa kelas 111 SDN Payungan 01 Kecamatan Kaliwungu Kabupaten Semarang Tahun Pelajaran 2016/2017.

Berdasarkan rumusan masalah dapat ditetapkan tujuan penelitian sebaagai berikut : Untuk meningkatkan hasil belajar matematika materi pecahan melalui model pembelajaran matematika realistik pada siswa kelas 111 SD Negeri Payungan 01 Kecamatan
Kaliwungu Kabupaten Semarang Tahun pelajaran 2016/2017.

\section{HASIL DAN PEMBAHASAN}

\section{HASIL}

Dari hasil refleksi diketaui bawa selama guru mengajar pada perbaikan pembelajaran siklus 1 suasana kelas masih kelihatan kaku,karena sebagian siswa masih sulit menangkap penjelasan guru meskipun sudah berulang-ulang menjelaskannya, memberikan materi prasarat, contoh/latihan soal. Pada siklus 11 siswa kelihatan lebih percaya diri, aktif dan berani mengajukan pertanyaan, suasana kelas lebih hidup dan antusius dalam mengikuti pelajaran.

\section{PEMBAHASAN}

\section{Pra Siklus}

Pembelajaran pra siklus mengajarkan tentang pecahan dan menggunakan rencana pengajaran. Proses pembelajaran diakhiri dengan tes yang akan dianalisa hasilnya untuk menentukan apakah pembelajaran tersebut berhasil atau tidak.

Guru sudah memberikan motivasi, materi prasarat, conto soal, dan kerja kelompok. Hal ini perlu dilaksanakan karena ketuntasan belajar siswa hanya mencapai $45 \%$ atau sebanyak 9 siswa dari 20 siswa, sedangkan ketidak tuntasan mencapai 55\% atau sebanyak 11 siswa.

Tabel 1. Hasil Perolehan Nilai Evaluasi Matematika Pra Siklus

\begin{tabular}{ccc}
\hline NO & Interval Nilai & Frekuensi \\
\hline 1 & $50-55$ & 5 \\
2 & $56-61$ & 6 \\
3 & $62-67$ & 1 \\
4 & $78-73$ & 4 \\
5 & $74-80$ & 4 \\
Jumlah & & 20 \\
Rata-rata & & 62 \\
\hline
\end{tabular}

Berdasarkan tabel tersebut hasil evaluasi mata pelajaran matematika pada materi pecahan kelas 111 SD Negeri Payungan 01 Kecamatan Kaliwungu. Sebelum kegiatan perbaikan pembelajaran dengan indeks kegagalan sebanyak 12 siswa atau jika diprosentasikan sebanyak $40 \%$ rentang nilai 50-55, 56-61, 62-67. Sedangkan indeks keberhasilan belajar siswa sesuai dengan KKM yaitu nilai kurang dari 65 hanya sebanyak 8 siswa atau $60 \%$ pada rentang nilai $68-73$ dan 74-80. 
Siklus 1

Dalam belajar dapat timbul berbagai masalah. Misalnya menciptakan suasana kelas yang baik agar belajar dapat berhasil menyesuaikan proses belajar dengan keunikan siswa,diagnosa kesulitan belajar.

Dalam penelitian tindakan kelas yang berasal dari kegagalan yang dialami guru dalam proses dan hasil pembelajaran, maka upaya perbaikan pembelajaran siklus 1 dilakukan dengan menitik beratkan pada pemberian motivasi belajar siswa,pemberian materi format, pemberian contoh soal dan latihan soal dapat meningkatkan hasil belajar siswa walaupun belum tuntas semua.

Tabel 2. Hasil perolehan nilai evaluasi Matematika siklus 1

\begin{tabular}{ccc}
\hline No & Interval nilai & Frekuensi \\
\hline 1 & $60-65$ & 7 \\
2 & $66-71$ & 3 \\
3 & $72-76$ & 6 \\
4 & $77-82$ & 3 \\
5 & $83-88$ & 1 \\
Jumlah & & 20 \\
Rata - rata & & 71.25 \\
\hline
\end{tabular}

Dari tabel diatas,menunjukkan bahwa nilai siswa pada kelas interval 60-65 sebanyak 7 siswa, kelas interval 66-71 sebanyak 3 orang siswa, kelas interval 72-76 sebanyak 6 siswa, rentang 77-82 sebanyak 3 siswa dan memperoleh nilai 83-88 sebanyak 3 siswa.. Untuk siklus 1 kami hanya menititk beratkan pada pemberian contoh soal,latihan soal,pemberian motivasi belajar pada siswa dan dalam pembelajaran lebih banyak menggunakan metode ceramah,dan siswa hanya mendengarkan penjelasan guru. Dari hasil analisis nilai terendah 60,nilai tertinggi 85 ,dan nilai rata-rata kelasnya adalah 71,25.

\section{Siklus 2}

Pada siklus 2 guru telah memotivasi belajar siswa dan telah menggunakan model pembelajaran Matematika Realistik dengan memanfaatkan media nyata sebagai alat bantu mengajar.
Tabel 3. Hasil perolehan nilai evaluasi Matematika siklus 2

\begin{tabular}{lll}
\hline No & Interval & Frekuensi \\
\hline $\mathbf{1}$ & $65-70$ & 3 \\
$\mathbf{2}$ & $71-76$ & 7 \\
$\mathbf{3}$ & $\mathbf{7 7 - 8 2}$ & 4 \\
$\mathbf{4}$ & $83-88$ & 5 \\
$\mathbf{5}$ & $89-94$ & 1 \\
Jumlah & $\mathbf{2 0}$ \\
Rata - rata & $\mathbf{7 8 . 2 5}$ \\
\hline
\end{tabular}

Tabel diatas menunjukkan pada kelas interval 65-70 sebanyak 3 siswa, 71-76 sebanyak 7 siswa, 77-82 sebanyak 4 siswa,83-88 sebanyak 4 siswa, 89-94 sebanyak 1 siswa.

Dari analisa data hasil belajar pembelajaran siklus 2 diketaui bahwa nilai yang diperoleh siswa terendah nilai 65 dan tertinggi nilai 90 dengan rata-rata kelas 78,25. Pada siklus 2 siswa kelihatan lebih percaya diri,aktif dan berani mengajukan pertanyaan, suasana kelas lebih hidup dan antusias dalam mengikuti pelajaran. Dengan demikian dapat disimpulkan bahwa perbaikan pembelajaran pada siklus 2 telah berhasil menuntaskan asil belajar siswa sehingga pembelajaran tidak perlu dilanjutkan ke siklus berikutnya.

\section{KAJIAN PUSTAKA}

Pada hakikatnya matematika merupakan suatu ilmu yang didasarkan atas akal (rasio) yang berhubungan benda-benda dalam pikiran yang abstrak. Beberapa

karakteristik dari matematika menurut Soedjadi (2007:13) adalah 1) memiliki objek kajian yang abstrak, 2) Bertumpu pada kesepakatan, 3) Berpola pikir deduktif, 4)Konsisten dalam sistem, 5) Memiliki simbul yang kosong dari arti, dan 6) memperhatikan semesta pembicaraan. Selanjutnya H.W. Fowler (dalam Muslich, 2008:221) menyatakan bahwa matematika merupakan mata pelajaran yang abstrak sehingga dituntut kemampuan guru untuk dapat mengupayakan strategi yaag tepat sesuai dengan tingkat perkembangan mental siswa. Menurut sejarah, matematika ditemukan dari hasil pengamatan dan pengalaman,dan dikembangkan dengan analogi dan coba-coba (trial and error). Selanjutnya generalisasi yang dibuat perlu diuji kebenarannya dengan menggunakan pola pikir deduktif, sehingga matematika disebut ilmu deduktif. Para ahli pendidikan matematika menyadari bahwa siswa mengalami kesulitan dalam mempelajari 
matematika dengan pendekatan deduktif yang jauh dari dunia nyata siswa. Untuk itu mengingat keabstrakan dari objek matematika maka pembelajaran untuk siswa yang baru pertama sekali mempelajari suatu materi perlu diupayakan dengan pendekatan induktif agar pembelajaran yang terjadi dapat berlangsung dalam dunia yang lebih nyata, sehingga akan mempermudah siswa memahaminya. Kemudian untuk seterusnya dapat beralih dengan pendekatan deduktif, karena akhirnya siswa tetap diharapkan mampu berpikir deduktif. Sebagaimana karakteristik dari matematika itu sendiri. Inilah kunci penting yang harus diketahui dan dimiliki oleh guru matematika.

Pembelajaran matematika dengan pendekatan induktif merupakan pembelajaran yang memungkinkan untuk mengaitkan materi yang akan disajikan dengan realita di sekitar siswa (dunia nyata). Pendekatan induktif digunakan dengan maksud disesuaikan dengan tahap perkembangan kognitif siswa dari konkret ke abstrak. Selanjutnya jika siswa sudah berada pada tahap berpikir formal diharapkan mereka dapat belajar dengan pendekatan deduktif.

Pendekatan realistik dicetuskan oleh seorang ahli pendidikan matematika pada Institut Freudental di Belanda bernama Hans Freudental. Pendekatan realistik merupakan pendekatan induktif dalam pembelajaran matematika yang memiliki landasan berpikir (filosofi) kontruktivisme. Pembelajaran dengan pendekatan realistik, siswa mengkonstrusikan sendiri pengetahuannya. Pengetahuan bukanlah seperangkat fakta, konsep, atau kaedah yang siap untuk diambil dan diingat. Siswa harus mengkonstruksikan pengetahuan dan memberi makna melalui pengalaman nyata. Siswa perlu dibiasakan untuk memecahkan masalah, menemukan sesuatu yang berguna bagi dirinya. Guru tidak mampu memberikan semua pengetahuan kepada siswa. Siswa harus mampu mengkonstruksikan pengetahuan dalam benaknya sendiri. Esensi dari teori konstruktivis adalah ide bahwa siswa harus menemukan dan menstransformasikan suatu informasi kompleks ke situasi lain.

Dengan dasar itu, pembelajaran harus dikemas menjadi proses 'mengkostruksi' bukan 'menerima' pengetahuan. Dalam proses pembelajran , siswa membangun sendiri pengetahuannya melalui kerterlibatan aktif dalam proses pembelajaran. Disini siswa yang menjadi pusat kegiatan, bukan guru. Hal ini didasarkan pada hakikat siswa sebagai individu yang mempunyai potensi untuk mencari dan mengembangkan dirinya. Lingkunganlah yang harus diciptakan untuk menunjang potensi siswa tersebut. Dalam rangka ini guru tidak perlu berdaya upaya menjejali siswa dengan segudang informasi, sehingga membuat anak didik tidak kreatif dalam mencari, menemukan, dan mengkonstruksikan pengetahuannya. Pembelajaran dengan pendekatan realistik lebih menekankan atau diutamakan pada 'strategi memperoleh pengetahuan' dibandingkan 'seberapa banyak siswa memperoleh dan mengingat pengetahuan'. Proses pembelajaran berlangsung alamiah dalam bentuk kegiatan siswa bekerja dan mengalami, bukan tansfer pengetahuan dari guru ke siswa. Strategi pembelajaran lebih diutamakan dari pada hasil pembelajaran. Pendekatan realistik dalam pembelajaran matematika merupakan batu sendi pembelajaran matematika sekolah yang dapat menanamkan konsep matematika secara utuh pada siswa.

Karakteristik pembelajaran dengan pendekatan realistik menurut Mukhlis (2005:23) adalah: 1) Mengawali pembelajaran matematika dengan masalah nyata, 2) Menggunakan model sebagai suatu jembatan antara real dan abstrak yang dapat membantu siswa belajar matematika pada level abstraksi. 3) Menggunakan produksi dan kontribusi siswa sendiri atau strategi sebagai hasil dari mereka, (doing mathematic).4) Memaksimalkan interaksi antara siswa- siswa, siswa- guru, dan siswa-sumber belajar. 5) mengaitkan materi matematika dengan topik matematika lainya (intertwin). Karakteristik pembelajaran dengan pendekatan realistik dikembangkan dari prinsip dasar desain pembelajaran matematika realistik, yaitu; 1) Penemuan kembali secara terbimbing dan prosen pematematisasi secara progresif, 2) Penomena bersifat mendidik. 3) Mengembangkan model sendiri. Ide utama dari pendekatan realistik adalah bahwa siswa harus diberi kesempatan untuk menemukan kembali (reinvent) konsep matematika dengan bimbingan orang dewasa (Gravemeijer, 1994). Dalam pandangan ini aktivitas anak merupakan hal yang penting. Oleh karena itu guru harus menyediakan ide-ide matematika untuk siswa. Hal ini hanya mungkin jika guru memberikan reaksi kepada siswa sehingga memungkinkan mereka untuk dapat menguasai matematika. 
Pendekatan realistik dalam pembelajaran menggunakan 'dunia nyata' yang konkret sebagai titik pangkal pembelajaran. Hal ini sangat relevan dengan pembelajaran matematika yang dikembangkan oleh Freudenthal (dalam Suryanto, 2000:110) yang menurutnya, matematika harus dihubungkan dengan kenyataan, berada dekat dengan siswa dan relevan dengan kehidupan masyarakat agar memiliki nilai manusiawi. Pandangannya menekankan bahwa bahwa materi matematika harus dapat ditransmisikan sebagai aktifitas manusia (human activity). Pembelajaran harus memberikan kesempatan siswa untuk reinvent (menemukan/menciptakan) matematika melalui praktek (doing it). Belajar sambil melakukan aktifitas (learning by doing) pengalaman belajar yang didapat oleh siswa lebih tahan lama tersimpan dalam benak siswa. Dengan demikian dalam pendidikan matematika, matematika seharusnya tidak sebagai sistem yang tertutup tetapi sebagai suatu aktifitas dalam proses pematematikaan. Hal ini dapat dilakukan melalui penyajian materi secara realistik dengan menggunakan 'dunia nyata'atau masalah nyata sebagai titik pangkal (starting point). Masalah nyata yang dimaksud bukan hanya karena titik tolak pembelajaran berhubungan dengan dunia nyata dalam arti sehari-hari, tetapi juga menekankan

pembelajaran dengan menyajikan sitiasi yang dapat dibayangkan (to image) oleh siswa itu sendiri. Jadi penekanannya pada membuat masalah itu menjadi nyata dalam pikiran siswa. Oleh karena itu situasi masalah yang digunakan untuk pembelajaran dengan pendekatan kontekstual harus mempunyai konteks atau kaitan dengan dunia nyata yang dipahami oleh siswa dalam arti sehari-hari, atau berkaitan dengan dunia yang dapat dibayangkan oleh siswa. Dalam hal ini Suryanto (2000:112) menyatakan bahwa dunia nyata yang dapat dibayangkan oleh siswa dapat berupa dunia pantasi, dunia dongeng, atau dunia matematika, asal saja dunia itu nyata dalam benak siswa.

Pembelajaran dengan pendekatan realistik harus memandang bahwa materi pelajaran matematika bukan sebagai 'hasil yang siap pakai'. Pembelajaran yang berdasarkan pandangan bahwa matematika adalah 'hasil yang siap pakai' hanya akan menuntut siswa mereproduksi materi yang telah diberikan atau membeo. Dalam hal demikian, kegiatan yang dapat ditugaskan kepada siswa adalah menerapkan rumus atau melakukan subtitusi. Ini tidak akan membuat kesan belajar yang relatif permanen dalam diri siswa. Tetapi pembelajaran matematika harus dipandang sebagai kegiatan, yaitu pembelajaran yang sebenarnya penekanannya pada upaya membantu siswa agar mampu mempelajari sesuatu (learning how to learn).

Langkah-langkah pembelajaran yang digunakan mencakup 5 karakteristik pembelajaran matematika realistik, adalah sebagai berikut.

kontekstual

\section{Langkah I. Menghadirkan masalah}

Guru memberikan masalah kontekstual yang dikemas dalam Lembar Kegiatan Siswa (LKS). Masalah kontekstual yang disajikan harus konkret dalam pemahaman siswa. LKS tersebut diberikan kepada setiap kelompok.

kontekstual.
Siswa menyelesaikan masalah kontekstual yang termuat dalam LKS secara berkelompok. Siswa diberi kebebasan untuk berdiskusi dalam kelompoknya dan menggunakan strateginya masing-masing untuk menyelesaikan masalah tersebut sehingga terjadi interaksi siswa dalam kelompok.

Langkah III. Mendiskusikan selesaian masalah kontekstual.

Berbagai jawaban dan pendapat siswa didiskusikan dalam diskusi kelas. Guru memberi kesempatan kepada siswa untuk membandingkan jawaban dengan kelompok lain. Guru memperhatikan aktivitas siswa dalam bertanya, memberikan pendapat, juga memposisikan dirinya sebagai mediator dalam diskusi. Langkah ini sampai semua siswa memahami konsep secara benar.

Langkah IV. Menyimpulkan materi pembelajaran

Guru mengarahkan siswa untuk membuat kesimpulan dari hasil diskusi kelas, sehingga diperoleh suatu konsep yang benar. Untuk menambah keterampilan matematika terutama prosedur pengerjaan guru memberikan tugastugas yang dikerjakan di luar kelas.

\section{Penerapan pada materi pecahan}

Pecahan adalah barang yang sudah dipecah atau pecahan dapat diartikan bilanganyang bukan bilangan bulat (KBBI 1990: 656). Menurut Sa 口dijah (2001: 74) bawa pecahan adalah suatu 
bentukpenulisan yang dapat dinyatakan sebagai $\frac{a}{b}$, dimana a dan $\mathrm{b}$ bilangan cacah dan $\mathrm{b} \neq 0$.

Untuk itu guru harus mampu menemukan suatu cara agar bisa membawa siswa lebih mudah dalam penanaman konsep materi tesebut dengan membawa anak ke situasi permasalahan yang nyata dalam kehidupan sehari-hari yang sering dialami siswa,misalnya rudi mempunyai 1 buah semangka,jika rudi akan membagikan keempat temannya maka masing-masing anak mendapat berapa bagian ? Jadi, dengan pertanyaan tadi diharapkan siswa dapat membangun atau mengkontruksikan pengetahuannya sendiri. Dari jawaban pertanyaan itu dimunculkan konsep pecahan. Jadi, bukan guru yang langsung mengumumkan, namun siswa yang mendapatkan arti 1:4

\section{SIMPULAN}

1. Pembelajaran Matematika yang realistik berorientasi pada pematematikasasian dari pengalaman dalam dunia nyata

2. Pembelajaran matematika yang realistik cocok diterapkan untuk siswa tingkat sekolah dasar yang taraf kognitifnya masih pada tingkat berpikir konkret, dunia nyata anak dapat menjembatani objek matematika yang bersifat abstrak

3. Pembelajaran matematika yang realistik merupakan pembelajaran matematika yang lebih terpusat pada kegiatan belajar siswa dengan dunia nyata sebagai titik pangkal pembelajaran.

4. Langkah-langkah penerapan pendekatan realistik dalam pembelajaran Matematika adalah 1) Menghadirkan masalah kontekstual 2) Menyelesaikan masalah kontekstual.

3) Mendiskusikan selesaian masalah kontekstual. 4) Menyimpulkan materi pembelajaran

\section{DAFTAR PUSTAKA}

Sutawijaya, A., Muhseno, G., Karim, M A., \& Soewito. (1991). Pendidikan Matematika lll. Jakarta: Depdikbud.

Jihad, A. (2008). Pengembangan Kurikulum Matematika. Bandung: Multi Pressindo.

Sa dijah, C. (2001). Pendidikan Matematika ll. Malang: Universitas Negeri Malang. 